\title{
T CELL SUBSETS' DISTRIBUTION IN ELITE KARATE ATHLETES AS A RESPONSE TO PHYSICAL EFFORT
}

\section{DISTRIBICIJA SUBSETOVA T ĆELIJA KOD VRHUNSKIH KARATISTA KAO REAKCIJA NA FIZIČKI NAPOR}

\author{
Dorota Kostrzewa-Nowak ${ }^{1,2^{*}}$, Rafał Buryta1,2,3, Robert Nowak ${ }^{1,2}$ \\ ${ }^{1}$ Department of Biological Bases of Physical Education, Faculty of Physical Education and Health Promotion, \\ University of Szczecin, Szczecin, Poland \\ ${ }^{2}$ Centre for Human Structural and Functional Research, Faculty of Physical Education and Health Promotion, \\ University of Szczecin, Szczecin, Poland \\ ${ }^{3}$ Pogoń Szczecin S.A. Soccer Club, Szczecin, Poland
}

\section{Summary}

Background: During karate fight muscles work at a very high intensity, and their contractions are extremely strong. The movement pattern contains a great number of feints, dodges, frequent changes in movements' tempo and direction, hits and kicks, all of which is highly stressful for athlete's organism, including the immune system.

Methods: T lymphocyte subsets' distribution and selected cytokines in peripheral blood of three elite karate athletes aged 30 years old (range $21-31$ years) with minimum 15 years of training experience were analysed in two experiments: at the beginning of the preparatory phase (a progressive test until exhaustion; an analysis of immune system's selected parameters and cardiorespiratory fitness measures, including $\mathrm{VO}_{2}$ max, $\mathrm{VE}, \mathrm{AT}, \mathrm{MVV}, \mathrm{MET}, \mathrm{Rf}$ ), and during the start-up period (Karate Championships; an analysis of selected parameters of the immune system).

Results: Maximal effort caused an increase in total lymphocyte percentage $(p<0.05)$. A decrease in Th cells in recovery $(p<0.05$ compared to post-exercise), and an increase in Th naïve cells in recovery $(p<0.05)$ were observed. A significant increase in $\mathrm{CD}^{+}$central memory cells $(p<0.05)$ was found only after the progressive test,

\begin{abstract}
Kratak sadržaj
Uvod: Tokom karate borbi aktivnost mišića je na vrlo visokom nivou, a same kontrakcije su ekstremno jake. Obrasci kretanja sportista uključuju veliki broj varki, izbegavanja udaraca, česte promene tempa i pravca kretanja, udarce rukama i nogama, a sve to je jako stresno za organizam sportiste, uključujući i imunosistem.

Metode: Sprovedena je analiza distribucije subsetova T limfocita i odabranih citokina u perifernoj krvi tri vrhunska karatista starosti oko 30 godina (u opsegu od 21 do 31 godine života) sa minimum 15 godina treniranja, i to u dva eksperimenta: na početku pripremne faze (progresivni test do iscrpljenosti; analiza odabranih parametara imunosistema i merenja kardiorespiratorne forme, uključujući $\mathrm{VO}_{2}$ max, VE, AT, MVV, MET, Rf), a takođe i na početku takmičenja (Karate šampionat; analiza odabranih parametara imunosistema).

Rezultati: Maksimalni napor je izazvao povećanje procenta ukupnih limfocita $(p<0,05)$. Primećeno je opadanje Th ćelija tokom oporavka $(p<0,05)$ u poređenju sa vrednostima posle treninga), kao i povećanje Th naivnih ćelija tokom oporavka $(p<0,05)$. Značajno povećanje $\mathrm{CD}^{+}$ centralnih memorijskih ćelija $(p<0,05)$ je zabeleženo samo
\end{abstract}

Address for correspondence:

Dorota Kostrzewa-Nowak

Faculty of Physical Education and Health Promotion, Department of Biological Bases of Physical Education University of Szczecin

40B Piastów Al., building 6, 71-065 Szczecin, Poland e-mail: dorota.kostrzewa-nowak@usz.edu.pl
List of abbreviations: APC, allophycocyanin; AT, anaerobic threshold; $\mathrm{BMI}$, body mass index; $\mathrm{BMR}$, basal metabolic rate; EDTA, ethylenediaminetetraacetic acid; FAT, percentage of fat; FBS, fetal bovine serum; FFM, fat free mass; FITC, fluorescein isothiocyanate; GM-CSF, granulocyte-macrophage colony-stimulating factor; MET, metabolic equivalent; $M V$, maximal voluntary ventilation; $\mathrm{PE}$, phycoerythrin; PerCP, peridinin chlorophyll protein; PerCP-Cy5.5, peridinin chlorophyll protein-cyanine 5.5; RC, respiratory compensation; Rf, respiratory frequency; RQ, respiratory quotient; TBW, total body water; TGF- $\beta$, transforming growth factor beta; TNF- $\alpha$, tumour necrosis factor alpha; $\mathrm{VE}$, maximum ventilation; $\mathrm{VO}_{2}$ max, maximum oxygen uptake. 
and no changes in both central and effector memory subsets of $\mathrm{CD}^{+}$cells during the first experiment. An increase $(p<0.05)$ in Treg and Th1 and a decrease $(p<0.05)$ in Th2 cells' distribution during recovery time were found. Additionally, changes $(p<0.05)$ in TNF- $\alpha, I L-6, I L-8, I L-10$ and IL-12p70 were observed.

Conclusions: Post-effort disorder in immune balance activated compensation pathways involving $\mathrm{CD} 4^{+}$cells. Treg and Th1 cells seem to be subsets of key importance involved in the anabolic effect of physical effort, at least among karate athletes.

Keywords: cytokines, flow cytometry, immunomodulation, physical exertion, $\mathrm{T}$ lymphocytes

\section{Introduction}

Although the idea of immune modulation in response to exercise is not novel, there is still a lack of data fully explaining the mechanisms of these changes. There is a lot of data confirming that regular physical activity has a beneficial impact on the immune system in sedentary subjects (1). On the other hand, it is well described that high-intensity and/or long-term physical effort causes adverse changes in both innate and adaptive immune systems of the participants $(2,3)$. The "Open Window Theory" is widely discussed in the literature. It is based on the immunosuppressive effect of physical effort, which lasts 3-72 hours after exercise, depending on the parameter measured $(4,5)$. However, cardiopulmonary capacity, as well as exercise-induced muscle adaptations process depend on the place and systemic inflammation (6-8).

The physical effort of martial arts belongs to a mixed type, both aerobic and anaerobic. Karate is an example of a sport in which speed plays a key role. The fight is going at an extreme pace. During a fight, muscles work at a very high intensity, and their contractions are extremely strong. The movement pattern contains a great number of feints, dodges, frequent changes in movements' tempo and direction, hits and kicks. It explains why karate combat competition performance is closely associated with athletes' strength and conditioning, physiological characteristics, skills, tactical decisions and psychological status. It is well known that an adequate training programme performed during the training in each phase of a season causes a disorder of homeostasis among athletes. Moreover, training or competition causes exercise-induced muscle damage that can result in a release of inflammatory signalling molecules and myocellular enzymes into the blood plasma (9-12).

Some of the most important components of the immune system are $B$ and $T$ lymphocytes. A number of $T$ cell subsets, e.g. T naïve, T memory, $T$ helper/inducer (Th), T suppressor/cytotoxic (Tc), $T$ regulatory (Treg) has been described. A common feature of these cells is an expression of membrane surface receptors including T-cell receptor (TCR), CD3 and posle progresivnog testa, a nisu primećene promene ni u centralnim ni u efektorskim subsetovima $\mathrm{CD} 4^{+}$ćelija tokom prvog eksperimenta. Zabeleženo je povećanje $(p<0,05)$ Treg i Th1, a smanjenje $(p<0,05)$ u distribuciji Th2 ćelija tokom perioda oporavka. Dodatno, primećene su promene $(p<0,05)$ u TNF- $\alpha$, IL-6, IL-8, IL-10 i IL-12p70.

Zaključak: Poremećaj imunološkog balansa posle fizičkog napora aktivirao je kompenzacione reakcije uključujući $\mathrm{CD}^{+}{ }^{+}$ćelije. Treg i Th1 ćelije su izgleda ključni subsetovi od značaja za anaboličke efekte fizičkog napora, bar kod karatista.

Ključne reči: citokini, protočna citometrija, imunomodulacija, fizički napor, $T$ limfociti

CD2. Taking the functionality into account, the Th $\left(\mathrm{CD} 4^{+}\right)$cells are divided into several subsets including Th1, Th2 and Th17 (13-16). The differentiation of naïve $\mathrm{T} \mathrm{CD}^{+}$cells is associated with their activation and production as well as the release of signalling molecules. It is well known that Th1 cells are responsible for synthesis and release of interferon gamma (INF- $\gamma$ ) and interleukin 2 (IL-2) being responsible for stimulation of Tc cell-associated immune response $(9,11)$. Th2 lymphocytes synthesise interleukins, including IL-4, IL-5, IL-10 and IL13, which are related to $B$ cell growing and differentiation. Therefore, Th2 cell subset is associated with humoral response modelling. It is also known that induction of cellular immune response is associated with enhanced humoral immune response, which is widely described as "immune deviation" (split tolerance) (17). Th17 cells are categorised as $\mathrm{CD}^{+}$cell subset expressing IL-1- (IL-1R) and IL-23 receptor (IL-23R) on their membrane surface. Those lymphocytes are responsible for the synthesis of such interleukins as IL-17A, IL-17F, IL-6, IL-21, IL-22, IL26 , and other signalling factors, e.g. tumour necrosis factor alpha (TNF- $\alpha$ ) and hematopoietic granulocytemacrophage colony-stimulating factor (GM-CSF) (18, 19). The development of T naïve into Th17 cells is stimulated by transforming growth factor beta (TGF$\beta), I L-6, I L-1 B, I L-7, I L-21$ and IL-23. Simultaneously, signalling molecules synthesised by Th1 and Th2 cells inhibit this process $(14,15,20)$. The presence of Th17 lymphocytes in peripheral blood is related to chronic inflammation and autoimmune diseases (15, $19,21,22)$. Same literature data evidenced that chronic high-intensity exercise could stimulate $T$ cells resulting in immunosuppression $(1,10,23)$. It might be manifested by an increased incidence of infections, mainly of the upper respiratory system among athletes. Interestingly, those changes are observed among young sportspeople, suggesting, that the immunological system can adapt to the influence of long-lasting high-bout exercises (23).

To our best knowledge, there is still a lack of data describing the lymphocyte differentiation process in association with training loads and exhaustive effort, including martial arts. Thus, to 
better understand the mechanism of biological adaption of the immune system to physical effort among professional karate athletes, we studied the $\mathrm{CD}^{+}$cell ( $T$ lymphocyte) subsets ${ }^{\prime}$ distribution in peripheral blood of elite athletes. The aim of the study was to assess the effect of training loads used at the preparation phase to start-up period and maximal effort $\left(100 \% \mathrm{VO}_{2}\right.$ max) achieved during the progressive efficiency test on the mechanical treadmill until exhaustion on $\mathrm{CD}^{+}$cell subsets' distribution. Additionally, selected cytokines' profile was determined to identify the immunological pathway associated with both training loads and maximal effort.

\section{Materials and Methods}

\section{Study design}

The study was designed to understand better the influence of exhaustive effort as well as training loads on selected immunological parameters among highly qualified elite karate athletes. The protocol of data collections included two experiments conducted at the beginning of the preparatory phase and during the start-up period.

The first experiment was performed after two weeks of the vacation time when the participants were asked to refrain from physical effort, especially training units. This experiment included a study of the impact of maximal effort on differentiation and distribution of selected $T$ cell subsets. To realise this experiment, $\mathrm{CD}^{+}$and $\mathrm{CD}^{+}{ }^{+} \mathrm{T}$ lymphocyte subsets related to their differentiation before, immediately after the progressive test, as well as during recovery time (about 17 hours after the test) were determined. Cardiorespiratory fitness measures: maximum oxygen uptake $\left(\mathrm{VO}_{2}\right.$ max $)$, maximum ventilation $(\mathrm{VE})$, anaerobic threshold (AT), respiratory quotient (RQ; volume ratio of emitted $\mathrm{CO}_{2}$ to oxygen uptake); respiratory compensation $(R C)$, maximal voluntary ventilation $(M V V)$, metabolic equivalent (MET) and respiratory frequency (Rf) were also determined.

The second experiment was performed at the end of the preparatory period to the $51^{\text {st }}$ European Senior Karate Championships, Montpellier, France, 2016. The samples were collected 24 hours before the departure for the championships and 24 hours after the return of the participants. The data obtained in this experiment were also compared with baseline values of participants' immunological characteristic obtained before the beginning of the training programme.

The studies were performed in the Biochemistry as well as Physiology Laboratories, Centre for Human Structural and Functional Research, Faculty of Physical Education and Health Promotion, University of Szczecin, Szczecin, Poland.

\section{Participants}

Three male elite karate athletes median aged 30 years old (range 21-31 years) with at least 15 years of training experience qualified to $51^{\text {st }}$ European Senior Karate Championships were recruited to the study. The participants competed in three different weight categories (kumite): $67 \mathrm{~kg}, 75 \mathrm{~kg}$ and $84+\mathrm{kg}$.

The baseline characteristic of the participants is demonstrated in Table I.

They had no history of any metabolic syndrome (according to International Diabetes Federation description: diabetes, prediabetes, abdominal obesity, high cholesterol and high blood pressure; www.idf. org/metabolic-syndrome) or cardiovascular diseases (defined by WHO as disorders of the heart and blood vessels; www.who.int/topics/cardiovascular_diseases/ en/). Participants were non-smokers and refrained from taking any medications or supplements known to affect metabolism. Participants were fully informed of any risks and discomfort associated with the experimental procedures before giving their written consent

Table I A baseline characteristic of the participants.

\begin{tabular}{|c|c|}
\hline Parameter & Median (min-max) \\
\hline Age [years] & $30(31-31)$ \\
\hline Height $[\mathrm{cm}]$ & $181(172-189)$ \\
\hline Weight [kg] & $75.2(66.8-86.8)$ \\
\hline BMI $\left[\mathrm{kg} / \mathrm{m}^{2}\right]$ & $23.0(22.6-24.3)$ \\
\hline BMR [kJ] & $8125(7188-9410)$ \\
\hline FAT [\%] & $11.1(10.9-12.7)$ \\
\hline FAT MASS [kg] & $9.6(7.3-9.6)$ \\
\hline $\mathrm{FFM}[\mathrm{kg}]$ & $65.7(59.5-77.2)$ \\
\hline TBW [kg] & $48.1(43.2-56.5)$ \\
\hline $\begin{array}{l}\text { length of training } \\
\text { experience [years] }\end{array}$ & $20(16-22)$ \\
\hline $\begin{array}{l}\text { weekly training } \\
\text { frequency [hours] }\end{array}$ & $9(9-9)$ \\
\hline
\end{tabular}

The table presents median (min-max) values characterising the participants.

Body mass and body composition were determined using Body Composition Analyzer Tanita BC-418MA (Tanita, Tokyo, Japan). $\mathrm{BMI}$ - body mass index, BMR - basal metabolic rate, FAT - the percentage of fat, FFM - fat-free mass, TBW - total body water. 
to participate. The study was approved by the Local Ethics Committee in accordance with the Helsinki Declaration.

\section{Data collection}

\section{Body composition}

The basic anthropometric indicators were measured in the morning, a day before the departure for the championships, in a laboratory room at $20-23{ }^{\circ} \mathrm{C}$. At least, 12 hours before measurement, participants did not perform any training or physical activity, and they had been prescribed an easily digestible diet, so as not to aggravate their digestive system. Additionally, measurements were performed at least $2 \mathrm{~h}$ after eating.

Participants' body mass and body composition parameters (body mass index (BMI), basal metabolic rate $(B M R)$, percentage of fat (FAT), fat free mass (FFM), total body water (TBW)), were determined using Body Composition Analyzer Tanita BC-418MA (Tanita, Tokyo, Japan) according to manufacturer's protocol.

The progressive efficiency test on the mechanical treadmill until exhaustion

The progressive efficiency test on a mechanical treadmill until exhaustion was chosen because of its advantages (did not require any special movement pattern skills, could be performed in laboratory conditions (with controlled and repetitive microenvironmental conditions) and let us use gas exchange data analyser combined with a treadmill). The test started with 5 minutes of warm-up running at the speed of $5 \mathrm{~km} / \mathrm{h}$. During the proper test, the speed increased by $2 \mathrm{~km} / \mathrm{h}$ after every 3 minutes of the test until exhaustion. The cardiorespiratory fitness measures $\left(\mathrm{VO}_{2}\right.$ max, $\mathrm{VE}, \mathrm{AT}, \mathrm{RQ}, \mathrm{RC}, \mathrm{MVV}, \mathrm{MET}$ and $\mathrm{Rf})$ were determined using state-of-the-art breath by breath gas exchange data analyser Quark CPET (Cosmed, Albano Laziale, Italy) (24). Additionally, every 3 minutes of the exercise, before increasing the workload (treadmill speed), finger capillary blood was taken for determination of lactate (LA) concentration. The LA concentrations were determined using mobile blood lactate monitoring system (THE EDGE Lactate Analyser, Apex Biotechnology Copr., Hsinchu, Taiwan).

\section{Blood sampling}

During the first experiment, blood samples were obtained tree times from the elbow vein: before the test (pre-exercise), no longer than 5 minutes after the test (post-exercise) and about 17 hours after the test, at the end of recovery time (recovery).
For the second experiment, the blood sampling from the elbow vein took place three times in the morning: before the beginning of training programme, 24 hours before the departure for the championships, and 24 hours after the return of the participants.

Each time, blood samples were taken into 7.5 $\mathrm{ml}$ S-Monovette tube with ethylenediaminetetraacetic acid (EDTA $K_{3}, 1.6 \mathrm{mg}$ EDTA $/ \mathrm{mL}$ blood) (SARSTEDT AG \& Co., Nümbrecht, Germany). All analyses were performed immediately after the blood collection.

\section{Flow cytometric analysis}

All flow cytometric analyses were performed using BD Accuri $^{\text {TM }}$ C6 flow cytometer (Becton Dickinson, Franklin Lakes, NJ, USA) and the results were calculated with the use of BD Accuri ${ }^{\mathrm{TM}} \mathrm{C} 6$ software (ver. 1.0.264.21) unless otherwise stated.

\section{Lymphocyte T, Th, and Tc subsets phenotyping}

Lymphocyte phenotyping in erythrocyte-lysed blood samples was performed using BD Multitest ${ }^{\mathrm{TM}}$ IMK kit (BD Biosciences, San Jose, CA, USA) was used. The expression of surface markers was determined according to the manufacturer's protocol. Briefly, an antibody cocktail to determine the percentages of $T$ lymphocyte subsets in erythrocytelysed blood samples was used. The cocktail contained antibodies including fluorescein isothiocyanate (FITC)-labelled CD3, phycoerythrin (PE)-labelled $\mathrm{CD} 8$, peridinin chlorophyll protein (PerCP)-labelled CD45, and allophycocyanin (APC)-labelled CD4.

After incubating the blood samples with appropriate aliquots of antibody cocktail (15 min, room temperature in darkness), a lysing solution was added. The samples were incubated in the darkness $(15 \mathrm{~min}$, room temperature) and then analysed by flow cytometry. For each sample, the fluorescence signal of at least $10^{4}$ ungated events was measured.

\section{Lymphocyte Th1 and Th2 subsets determination}

To determine Th1 and Th2 cell subsets, Human Th1/Th2/Th17 Phenotyping Kit (BD Biosciences). Briefly, an antibody cocktail to determine the percentages of Th1 and Th2 lymphocyte subsets in erythrocyte-lysed blood samples was used. The cocktail contained antibodies including FITC-labelled interferon-gamma, peridinin chlorophyll proteincyanine 5.5 (PerCP-Cy5.5)-labelled CD4, and APClabelled IL-4. The cells were fixed with BD Cytofix ${ }^{\text {TM }}$ fixation buffer (20 $\mathrm{min}$, room temperature), then washed using BD Perm/Wash ${ }^{\mathrm{TM}}$ buffer and suspended in BD Perm/Wash ${ }^{\mathrm{TM}}$ buffer for 15 minutes (room temperature in the darkness). After that, the buffer was removed, and the antibodies-containing cocktail 
was added. After $30 \mathrm{~min}$ of incubation (room temperature in the darkness), the cells were washed with BD Perm/ Wash ${ }^{\mathrm{TM}}$ buffer and suspended in stain buffer (FBS) prior to flow cytometric analysis. For each sample, the fluorescence signal of at least $10^{4}$ gated events for the forward and side light-scatter characteristics of lymphocytes was measured.

\section{Lymphocyte Th17 and Treg subsets determination}

To determine Th17 and Treg cell subsets, HumanTh17/Treg Phenotyping Kit (BD Pharmingen ${ }^{\text {TM }}$, San Jose, CA, USA) was used. Briefly, an antibody cocktail to determine the percentages of Th17 and Treg lymphocyte subsets in erythrocyte-lysed blood samples was used. The cocktail contained antibodies including PE-labelled IL-17A, PerCP-Cy5.5-labelled CD4, and Alexa Fluor ${ }^{\circledR}$ 647-labelled FoxP3. The cells were fixed with Human FoxP3 buffer $(20 \mathrm{~min}$, room temperature in the darkness), then washed twice and suspended in stain buffer (FBS). After that, an appropriate aliquot of antibody cocktail was added, and the samples were incubated for $40 \mathrm{~min}$ (room temperature in the darkness). Then, the cells were washed twice with stain buffer (FBS) and analysed. For each sample, the fluorescence signal of at least $10^{4}$ gated events for the forward and side light-scatter characteristics of lymphocytes was measured.

\section{Memory $T$ cell subsets phenotyping}

The analysis of $\mathrm{CD}^{+}$memory $\mathrm{T}$ cell subsets in erythrocyte-lysed blood samples was performed using Human Naïve/Memory T Cell Panel (BD Pharmingen $\left.^{\text {TM }}\right)$, and anti-CD8 ${ }^{+}$fluorescence labelled antibodies (BD Pharmingen ${ }^{\mathrm{TM}}$ ) according to manufacturer's protocol. Briefly, two different cocktails of antibodies (one for $\mathrm{CD}^{+}$cells and one for $\mathrm{CD}^{+}$cells, respectively) containing Alexa Fluor ${ }^{\circledR}$ 647-labelled Mouse AntiHuman CD197 (CCR7), PerCP-Cy ${ }^{\text {TM }}$ 5.5-labelled Mouse Anti-Human CD4, or PE-labelled CD8, and FITClabelled Mouse Anti-Human CD45RA, were prepared prior to use. After incubating the blood samples with appropriate aliquots of antibody cocktails (20 min, room temperature in darkness), a lysing solution was added. The samples were gently mixed, incubated in the darkness ( $15 \mathrm{~min}$, room temperature) and then analysed by flow cytometry. For each sample, the fluorescence signal of at least $5 \times 10^{4}$ ungated events was measured. The analysed $\mathrm{CD}^{+}{ }^{+} \mathrm{SSC}^{\mathrm{low}}$ or $\mathrm{CD} 8^{+} \mathrm{SSC}^{\text {low }}$ cells were determined as T Naïve $\left(\mathrm{CD}_{4} 5 \mathrm{RA}^{+} \mathrm{CD}_{197^{+}}\right)$, T central memory $\left(\mathrm{T}_{\mathrm{CM}} ; \mathrm{CD} 45 \mathrm{RA}^{-} \mathrm{CD} 197^{+}\right)$and $\mathrm{T}$ effector memory ( $\left.T_{E M} ; C C_{4} 4 R^{-} C D 197^{-}\right)$subsets, respectively. Quadrants for the dot plots to determine percentages of each $\mathrm{CD}^{+}$or $\mathrm{CD}^{+}$memory $\mathrm{T}$ cell subsets were derived using appropriate fluorescence-minus-one (FMO) controls.

\section{Selected cytokine profile}

The measurement of selected cytokines, namely interleukin-8 (IL-8), interleukin-1 (IL-1 ), interleukin6 (IL-6), interleukin-10 (IL-10), tumour necrosis factor alpha (TNF- $\alpha$ ), and interleukin-12p70 (IL-12p70) protein levels in analysed blood plasma samples was performed using BD Cytometric Bead Array (CBA) Human Inflammatory Cytokines Kit (BD Biosciences) according to manufacturer's protocol. Briefly, an appropriate aliquot of mixed capture beads was prepared and incubated with serum enhancement buffer in the darkness (30 $\mathrm{min}$, room temperature). Recombinant standards were diluted (in the rage 0 $1: 1024)$ to prepare standard curves. Then, an appropriate aliquot of each dilution of recombinant standard or analysed plasma sample was added to the capture beads, gently mixed and incubated for 1.5 hours in the darkness (room temperature). After washing the samples, the detection reagent was added, gently agitated and incubated for another 1.5 hours (in the darkness, room temperature). Then, the samples were washed, the fresh wash buffer was added, and the samples were analysed by flow cytometry. For each sample, the fluorescence signal of 2100 events gated for beads population was measured. Results were calculated using FCAP Array $^{T M}$ Software (ver. 3.0.1; Soft Flow Hungary Ltd., Pecs, Hungary).

\section{Statistical analysis}

All data are presented as median (min-max). Statistical analysis was performed using STATISTICA (data analysis software system), version 12 software (StatSoft, Inc., 2014). Significance levels of differences observed between analysed time points (pre-exercise vs. post-exercise vs. recovery, as well as baseline vs. before championships vs. after championships) were assessed using Friedman's analysis of variance (Friedman's ANOVA) followed by Dunn's test with Bonferroni correction. Each time, $\mathrm{p} \leq 0.05$ was considered a significant difference.

\section{Results}

The baseline characteristics of body composition, as well as the length of training experience and weekly training frequency of the participants, are presented in Table I. All karate athletes qualified for the experiment were subjected to the same training programme and training loads during the experiment. The baseline characteristic of a studied subset of $T$ $\left(\mathrm{CD}^{+}\right)$cells' distribution, as well as cytokines' profile in peripheral blood, were determined at the beginning of the preparatory stage of the training programme (after two weeks of the vacation time). To define the impact of maximal effort on differentiation and distribution of selected $\mathrm{CD}^{+}$cell subsets in karate 
Table II The cardiorespiratory fitness measures of participants during the progressive test until exhaustion.

\begin{tabular}{|l|c|}
\hline Parameter & median (min-max) \\
\hline $\mathrm{VO}_{2 \mathrm{max}}[\mathrm{mL} / \mathrm{kg} / \mathrm{min}]$ & $55.2(52.7-57.8)$ \\
\hline AT $[\mathrm{beats} / \mathrm{min}]$ & $158(151-169)$ \\
\hline $\mathrm{RQ}$ & $1.07(1.04-1.10)$ \\
\hline $\mathrm{RC}$ & $175(163-190)$ \\
\hline $\mathrm{V}_{\mathrm{E}}[\mathrm{L} / \mathrm{min}]$ & $152.1(130.1-178.8)$ \\
\hline $\mathrm{MVV}[\mathrm{L} / \mathrm{min}]$ & $201.3(194.3-204.8)$ \\
\hline $\mathrm{MET}[\mathrm{mL} / \mathrm{kg} / \mathrm{min}]$ & $15.5(15.0-16.5)$ \\
\hline Rf & $56.8(48.5-64.7)$ \\
\hline
\end{tabular}

The table presents median (min-max) values.

The analyses were performed using state-of-the-art breath by breath gas exchange data analyser Quark CPET (Cosmed, Albano Laziale, Italy).

$\mathrm{VO}_{2 \text { max }}$ - maximum oxygen uptake; $\mathrm{AT}$ - anaerobic threshold; $\mathrm{RQ}$ - respiratory quotient (volume ratio of emitted $\mathrm{CO}_{2}$ to oxygen uptake); $\mathrm{RC}$ - respiratory compensation; $\mathrm{V}_{\mathrm{E}}$ - minute ventilation; MVV - maximal voluntary ventilation; MET metabolic equivalent; Rf - respiratory frequency.

athletes' peripheral blood, the progressive test until exhaustion on the mechanical treadmill in laboratory conditions at the beginning of the preparatory stage was performed. The test was carried out in the morning, a day before the beginning of the training programme. The participants' cardiorespiratory fitness measures obtained during the progressive test are presented in Table II. Additionally, to explain the impact of total training units and the competitions on $\mathrm{CD}^{+}{ }^{+}$cells' ( $\mathrm{T}$ lymphocytes) differentiation and distribution, as well as cytokine profile of participants' blood, they were analysed 24 hours before the departure for championships and 24 hours after the return of the participants.

It was found that maximal effort caused significant $(\mathrm{p}<0.05)$ changes in both total lymphocytes $\left(\mathrm{CD} 45^{+} \mathrm{SSC}^{\text {low }}\right.$ cells) counts (data not presented) and distribution (Figure 1A), while no changes in this parameter were observed during recovery time (Figure 1A). A similar pattern of lymphocytes' distribution was observed in the second experiment (Figure $1 B)$, yet the changes were not statistically significant. Our study showed that significant $(p<0.05)$ changes in Th naïve $\left(C D 4{ }^{+} \mathrm{CD}_{45} \mathrm{RA}^{+}\right.$), as well as Th $\left(\mathrm{CD}^{+}\right.$ CD4 ${ }^{+}$) cells, were observed after the maximal effort. Significant $(p<0.05)$ increase in Th cells in recovery time (recovery), as well as in Th naïve cells imme- diately after the test (post-exercise) were observed (Figure 1A). It must be emphasised that in recovery time the median of Th naïve cells was ca. 10\% higher than baseline values found before the test (preexercise) (Figure 1A). No significant changes in both $\mathrm{CD4}^{+}$and $\mathrm{CD}^{+}{ }^{+}$T naïve $\left(\mathrm{CD} 45 \mathrm{RA}^{+} \mathrm{CD} 197^{+}\right)$cells were found after the training programme and after the returning from championships (Figure 1B). Additionally, a significant $(p<0.05)$ increase in $C D 8^{+}$ central memory cell $\left(\mathrm{Tc}_{\mathrm{CM}}\right)$ percentage was found only after the progressive test and no changes in both central $\left(T h_{C M}\right)$ and effector $\left(T h_{E M}\right)$ memory subsets of $\mathrm{CD} 4{ }^{+}$cells during the first experiment (Figure $2 \mathrm{~A}$ ). There were no differences in the distribution of $\mathrm{CD}_{4}{ }^{+}$ and $\mathrm{CD}^{+}$memory cells (both central and effector ones) in response to the training programme, as well as direct sports competition loads compared to the baseline distribution pattern (Figure $2 B$ ). On the other hand, a significant $(p<0.05)$ increase in Treg $\left(\mathrm{CD}^{+}{ }^{+} \mathrm{FoxP}^{+}\right)$and Th1 $\left(\mathrm{CD}^{+}{ }^{+} \mathrm{FN}-\gamma^{+}\right)$, as well as significant decrease in Th2 $\left(\mathrm{CD} 4^{+} \mathrm{IL}-4^{+}\right)$cells' distribution during recovery time in comparison to pre-test, were found. The median of Treg cells' percentage was almost 8-fold higher than the baseline value, while the median of Th1 cells' percentage was about 2.5-fold higher than the baseline values found during the first experiment (Figure 2A). Opposite to this observation, Th1 cell percentage before the championships was 3.5 -fold higher $(p<0.05)$ than the baseline characteristic of these cell subsets during the second experiment (Figure 2B).

To obtain a more complete representation of the immunomodulatory effect of physical effort, cytokine profiles in plasma of studied participants were examined. Six plasma cytokines levels were determined, yet the IL-1 plasma level was below the method's detection limit in all analysed time points (data not presented). It was observed that only TNF- $\alpha$ concentration was higher after the progressive test in comparison to preexercise $(p<0.05)$ plasma level, while no significant changes in IL-12p70, IL-6 and IL-8 were found. The increases in IL-6 and IL-8 plasma concertation were significant during the recovery time in comparison to pre-test values $(p<0.05)$. The median of IL-6 concentration was ca. 6.5-fold higher while the median of IL-8 concentration was ca. 3-fold higher than baseline values (Figure $3 A$ ). Examining the influence of total training units on studied cytokines level, a significant increase $(p<0.05)$ in IL-12p70 and IL-10 were observed in comparison to baseline values. Our study did not demonstrate an impact of direct sports competition effect on any of studied cytokines in comparison to baseline values (Figure 3B). 

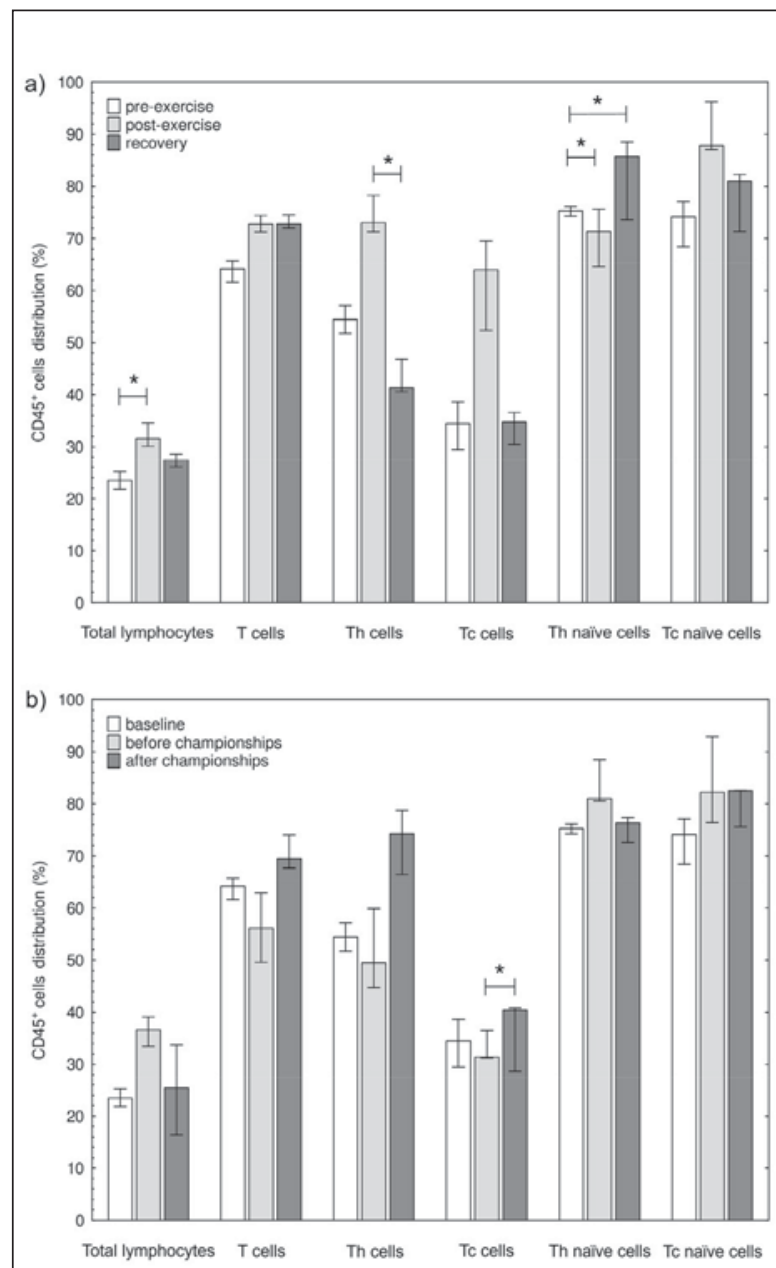

Figure 1 Median of the percentage of white blood cells lymphocyte $\left(\mathrm{CD} 45^{+}\right)$subsets, including: $\mathrm{T}$ cells $\left(\mathrm{CD} 3^{+}\right)$, helper/ inducer $\mathrm{T}$ cells $\left(\mathrm{Th} ; \mathrm{CD}^{+}\right)$, suppressor/cytotoxic $\mathrm{T}$ cells (Tc; $\mathrm{CD}^{+}$), helper/inducer naïve $\mathrm{T}$ cells (Th naïve; $\mathrm{CD}^{+}$ CD45RA ${ }^{+} \mathrm{CD} 197^{+}$), suppressor/cytotoxic naïve $\mathrm{T}$ cells (Tc naïve; $\mathrm{CD}^{+}{ }^{+} \mathrm{CD} 45 \mathrm{RA}^{+} \mathrm{CD} 197^{+}$) of studied participants' blood samples determined: A) before (pre-exercise) and after the progressive test on mechanical treadmill until exhaustion (5 minutes post-exercise and during recovery time, about 17 hours after the test), B) before the beginning of training programme (baseline), 24 hours before the departure for the $51^{\text {st }}$ European Senior Karate Championships, Montpellier, France, 2016 and 24 hours after the return of the participants. The bar represents median; whiskers represent the min-max range.

Significance levels of differences observed between analysed time points (pre-exercise vs. post-exercise vs. recovery, as well as resting vs. before championships vs. after championships) were assessed using Friedman's analysis of variance followed by post-hoc Dunn's test with Bonferroni correction.

* $p<0.05$
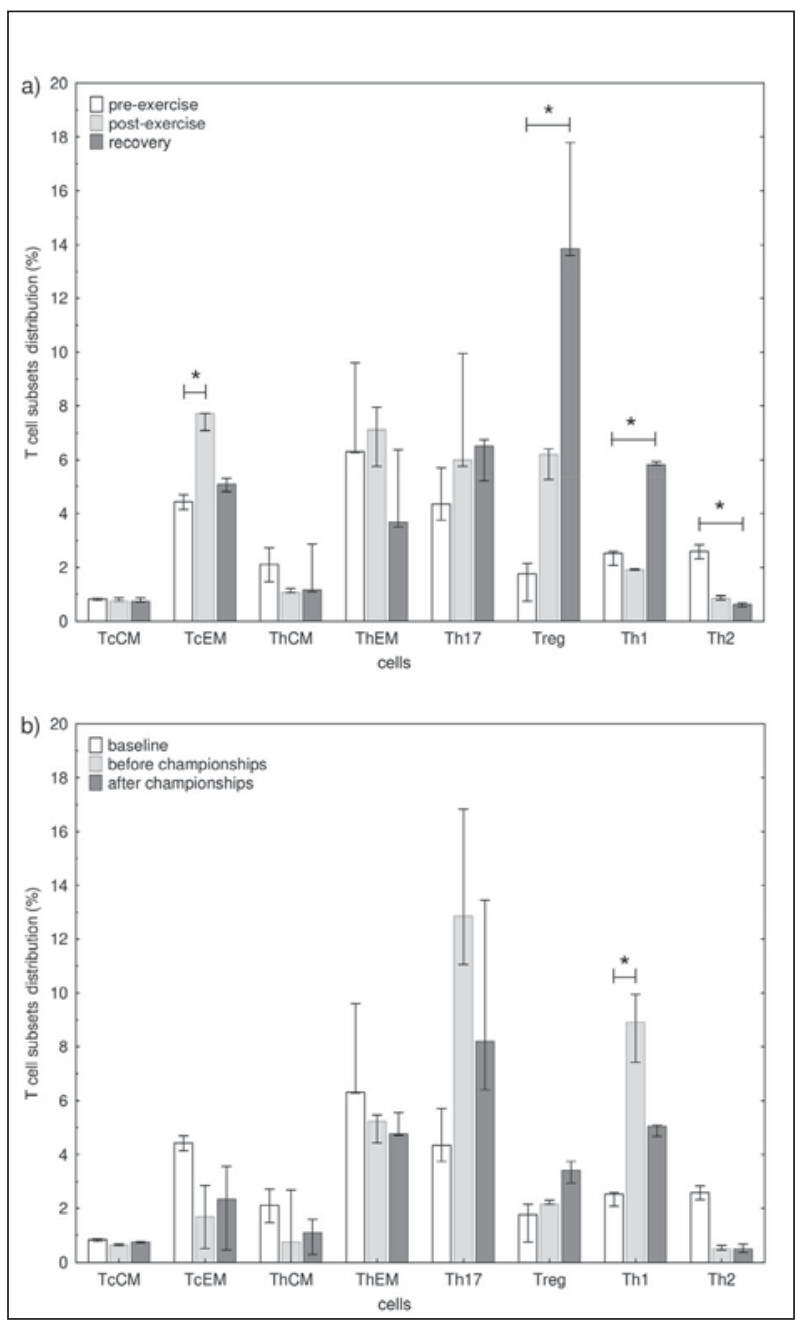

Figure 2 Median of the percentage of T lymphocyte subsets including: Tc central memory cells ( $\mathrm{TC}_{\mathrm{CM}} ; \mathrm{CD} 8^{+} \mathrm{CD} 45 \mathrm{RA}^{-}$

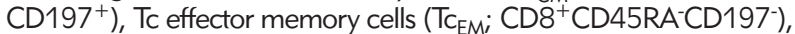
Th central memory cells $\left(\mathrm{Th}_{\mathrm{CM}} ; \mathrm{CD}^{+}{ }^{+} \mathrm{CD} 45 \mathrm{RA}{ }^{-} \mathrm{CD} 197^{+}\right)$, Th effector memory cells (Th $\left.\mathrm{EM}_{\mathrm{C}} \mathrm{CD}^{+}{ }^{+} \mathrm{CD} 45 \mathrm{RA}^{-} \mathrm{CD} 197^{-}\right)$, Th17 cells $\left(C D 4^{+} \mathrm{IL}-17 \mathrm{~A}^{+}\right)$, regulatory $\mathrm{T}$ cells $\left(\right.$ Treg; $\mathrm{CD} 4^{+}$FoxP3 ${ }^{+}$), Th1 cells $\left(\mathrm{CD} 4^{+} \mathrm{IFN}-\gamma^{+}\right)$and Th2 $\left(\mathrm{CD} 4^{+} \mathrm{IL}-4^{+}\right)$cells of studied participants' blood samples determined: A) before (preexercise) and after the progressive test on mechanical treadmill until exhaustion ( 5 minutes post-exercise and during recovery time, about 17 hours after the test), B) before the beginning of training programme (baseline), 24 hours before the departure for the $51^{\text {st }}$ European Senior Karate Championships, Montpellier, France, 2016 and 24 hours after the return of the participants.

The bar represents median; whiskers represent the min-max range.

Significance levels of differences observed between analysed time points (pre-exercise vs. post-exercise vs. recovery, as well as resting vs. before championships vs. after championships) were assessed using Friedman's analysis of variance followed by post-hoc Dunn's test with Bonferroni correction.

* $p<0.05$ 

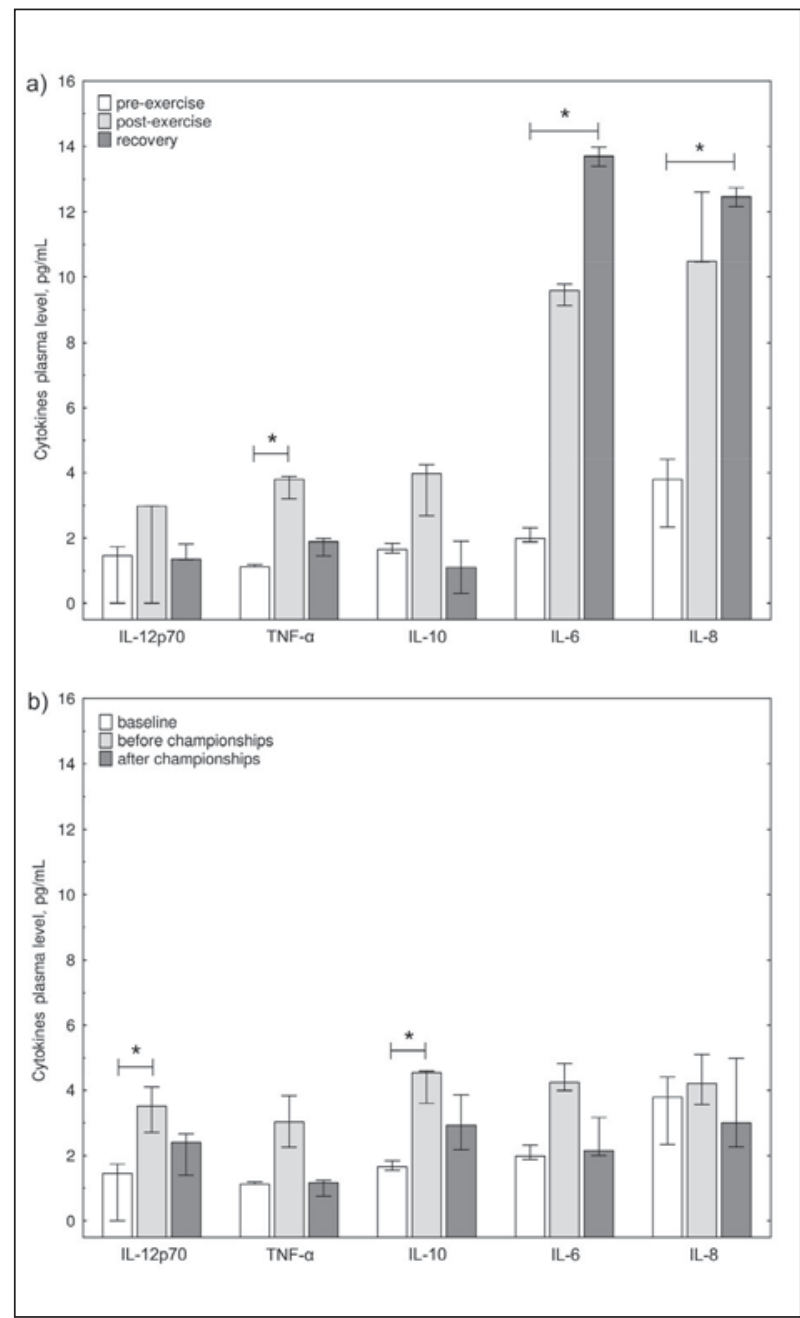

Figure 3 The plasma cytokine profile including interleukin12 p70 (IL-12p70), tumour necrosis factor alpha (TNF- $\alpha$ ), interleukin-10 (IL-10), interleukin-6 (IL-6) and interleukin-8 (IL-8) of studied participants' blood samples determined: A) before (pre-exercise) and after the progressive test on mechanical treadmill until exhaustion ( 5 minutes post-exercise and during recovery time, about 17 hours after the test), B) before the beginning of training programme (baseline), 24 hours before the departure for the $51^{\text {st }}$ European Senior Karate Championships, Montpellier, France, 2016 and 24 hours after the return of the participants.

The bar represents median; whiskers represent the min-max range.

Significance levels of differences observed between analysed time points (pre-exercise vs. post-exercise vs. recovery, as well as resting vs. before championships vs. after championships) were assessed using Friedman's analysis of variance followed by post-hoc Dunn's test with Bonferroni correction.

* $\mathrm{p}<0.05$

\section{Discussion}

Immunomodulatory effect of physical effort is widely discussed in the literature $(9,10,16,25)$. It seems that lymphocytes being an extremely adaptable group of white blood cells are good candidates for investigation of the biological mechanism of the immune system's adaptive pathway in high-qualified athletes. Taking a pleiotropic role of $\mathrm{T}\left(\mathrm{CD}^{+}\right)$cells into account, those subsets seem to be very important in keeping the homeostatic balance between pro- and anti-inflammatory signalling pathway associated with the different type and time period of physical effort.

Generally, lymphocytopenia was observed after the progressive test, but only the Th $\left(\mathrm{CD} 3^{+} \mathrm{CD} 4^{+}\right)$ cell percentage was increasing. The decreases in senescent $\mathrm{CD}_{4}^{+}$and $\mathrm{CD} 8^{+}$T lymphocytes percentages were described in the trained athletes compared with the untrained group after maximal exercise (26). Some studies evidenced the changes in distribution between naïve and senescent $T$ cells (more naïve $\mathrm{CD}^{+}$and less senescent $\mathrm{CD} 4^{+}$and $\mathrm{CD}^{+}{ }^{+}$cells) among resting athletes with high $\mathrm{VO}_{2}$ max (maximal aerobic capacity) values in comparison to their counterparts with lower $\mathrm{VO}_{2}$ max values (27). According to Simpson, the immune system in regular training subjects creates space for naïve $T$ lymphocytes by mobilisation of senescent $T$ cells (28). He explains this phenomenon by a negative feedback loop: the decrease in peripheral $T$ lymphocytes is caused by apoptosis of senescent T cells; this gap is filled up by naïve $T$ lymphocytes leaving thymus (28). It was assumed by Brown et al. that such feedback loop should be more intense in regularly training participants. He also confirmed this assumption observing a dull senescent $T$ lymphocyte response and a concomitant increase in naïve $T$ cells among trained individuals compared to untrained counterparts (26). Our results are also in line with this theory.

Our study investigated the peripheral distribution of $\mathrm{CD}^{+}$cells' subtests, including young and undifferentiated naïve (both $\mathrm{CD}^{+}$and $\mathrm{CD} 4^{+}$), as well as memory (central and effector) $T$ cells and differentiated T lymphocytes (e.g. Th1, Th2, Treg). The results indicated that maximal effort $(100 \%$ $\mathrm{VO}_{2}$ max) stimulates a shift in the distribution of $\mathrm{CD}^{+}$cells, both adolescent and naïve ones.

Interleukin 8 and IL-6 are cytokines responsible for stimulation of haematopoiesis (1). The increased post-test IL- 6 concertation and rising IL-8 concentration during the recovery time might be a functional explanation of releasing $\mathrm{CD}^{+}$naïve $\mathrm{T}$ cells into circulation. The increase in IL- 6 plasma concentration observed during the recovery time seems to confirm the hypothesis that this interleukin released from contracting muscle during the exercise acts in a hormone-like manner and mobilises extracellular substrates and/or augments substrate delivery (1). It seems that the pro-inflammatory effect of IL-6 is 
related more with the anabolic effect of the maximal effort than with the inflammation process.

Additionally, during the recovery time after such an exhaustive effort, a significant increase in Treg distribution was found. Regulatory $T$ lymphocytes (Treg) forming $5-15 \%$ of whole Th $\left(\mathrm{CD}^{+}\right)$lymphocyte pool, are responsible for the important phenomenon of immunologic self-tolerance. They inhibit dangerous autoimmune responses, suppress activated effector T lymphocytes as well as antigen-presenting cells that is mediated by a variety of mechanisms (15). From this point of view, the changes in Treg cells' distribution are probably related with the homeostatic role of those cells and evidence that inflammation being a consequence of maximal effort is a short-term phenomenon, at least in case of the studied male elite karate athletes. On the other hand, post-exercise changes in IL-12p70, TNF- $\alpha$, IL-10, IL6 and IL-8 were not statistically significant except for TNF- $\alpha$. This observation combined with $\mathrm{CD}^{+}{ }^{+}$cells' distribution evidenced that the progressive test did not cause a strong and rapid inflammation but had a modulated impact on the immune status of studied participants. Moreover, a significant increase in Th1 cell percentage found during recovery time indicated that modulating effect of maximal effort in laboratory condition might be related with activating macrophages because of the secreting of large quantities of IFN- $\gamma$ and lymphotoxin (15). On the other hand, a significant decrease in Th2 cells was observed during the recovery after the maximal effort. Opposed to our results, some literature data indicated a significantly increased level of interleukin 4 (IL-4) during recovery time suggesting that post-effort changes during 3-72 hours were associated with Th2 cells' response (29). Our study evidenced that natural immune response to $100 \% \mathrm{VO}_{2}$ max effort stimulates aggressive, Th1related pro-inflammatory state and enhances protective, Th2-related immune profile. The protective and regulatory role of the immune system is associated with Treg cells presence in peripheral blood during the recovery.

In opposite to exhausting effort achieved on the treadmill, the distribution of $\mathrm{CD} 45^{+} \mathrm{SSC}^{\text {low }}$, as well as $\mathrm{CD}^{+}$cell percentages, did not change significantly in start-up period and after the competition in comparison to their baseline values. Only a slight but significant increase in $\mathrm{CD}^{+}{ }^{+} \mathrm{CD} 8^{+}$cells was found after the championship. This change may be associated with post-travel fatigue. The significant changes in white blood cells' distribution were observed after a different type of training programme associated with different type of martial arts in sedentary subjects (e.g. tai chi chuan exercise) as well as in professional athletes (e.g. taekwondo or mixed martial arts) (30-32). On the other hand, literature data suggest that regular exercise noticeably decreases the level of pro-inflammatory cytokines such as TNF- $\alpha$, or IL- 6 in circulation. It suggests an anti-inflammatory effect of regular exercise, especially practised for a long time (25). Our results suggested that the immunomodulating effect of start-up period is related with an increase in IL-12p70 and IL-10 cytokines level that play a crucial role in the activation of studied cells and are also related to haematopoiesis stimulation. IL-10 participates in the antiinflammatory response to the exercise $(1,10)$ playing a crucial role in muscle tissue regeneration (33). Many authors reported this phenomenon after intense and prolonged exercise $(12,33,34)$. IL12 p70 is a typical pro-inflammatory cytokine and its increase in pre-championship studied time point may help to explain a significant increase in aggressive, Th1-related cell profile.

\section{Perspectives}

The understanding how the organism's functional potential, especially immune mediators regulate its adaptation in response to different type of effort seems to be important for coaches and sports scientists to develop practical strategies to enhance an athlete's performance. A better understanding of $\mathrm{CD}^{+}{ }^{+}$cells' differentiation and distribution in athletes' peripheral blood may help to avoid the negative effect of chronic high-intensity exercise stimulation of T cells resulting in immunosuppression. On the other hand, understanding of the immunomodulatory effect of $T$ cells may be helpful in the better planning of training loads to induce a microinflammation anabolic effect of the immune system. Our study indicated that both start-up period, as well as maximal effort on the treadmill, caused disorder in immune balance and activation of compensation pathways with the participation of primarily $\mathrm{CD} 4^{+}$cells. It seems that Treg and Th1 cells are the key subsets involved in the anabolic effect of physical effort, at least among karate athletes.

However, it should be strongly emphasised that the results of this study may help to build a new hypothesis useful to searching an explanation of widely disused "Open Window Theory" and have a character of a pilot study, needing further investigation.

Acknowledgements. The authors would like to thank the individuals who volunteered to participate in the study. The study was financially supported by the Faculty of Physical Education and Health Promotion, University of Szczecin.

\section{Conflict of interest statement}

The authors stated that they have no conflicts of interest regarding the publication of this article. 


\section{References}

1. Petersen AM, Pedersen BK. The anti-inflammatory effect of exercise. J Appl Physiol (1985) 2005; 98: 1154-62.

2. Córdova A, Sureda A, Tur JA, Pons A. Immune response to exercise in elite sportsmen during the competitive season. J Physiol Biochem 2010; 66: 1-6.

3. Collinson P. Laboratory medicine is faced with the evolution of medical practice. J Med Biochem 2017; 36: $211-5$.

4. Kostrzewa-Nowak D, Nowak R, Chamera T, Buryta R, Moska W, Cięszczyk P. Post-effort chances in C-reactive protein level among soccer players at the end of the training season. J Strength Cond Res 2015; 29: 1399-405.

5. Parisotto R, Pyne D, Martin D, Gore C, Fallon K, Fricker $P$, Hahn A. Neutropenia in elite male cyclists. Clin J Sport Med 2003; 13: 303-5.

6. Guarner V, Rubio-Ruiz ME. Low-grade systemic inflammation connects aging, metabolic syndrome and cardiovascular disease. Interdiscip Top Gerontol 2015; 40: 99-106.

7. Mikkelsen UR, Langberg H, Helmark IC, Skovgaard D, Andersen LL, Kjaer M, Mackey AL. Local NSAID infusion inhibits satellite cell proliferation in human skeletal muscle after eccentric exercise. J Appl Physiol (1985) 2009; 107: 1600-11.

8. Sultan $P$, Edwards MR, Gutierrez del Arroyo A, Cain D, Sneyd JR, Struthers R, Minto G, Ackland GL. Cardiopulmonary exercise capacity and preoperative markers of inflammation. Mediators Inflamm 2014:727451. http://dx.doi.org/10.1155/2014/727451.

9. Fatouros IG, Jamurtas AZ. Insights into the molecular etiology of exercise-induced inflammation: opportunities for optimizing performance. J Inflamm Res 2016; 9: 175-86.

10. Ghafourian M, Ashtary-Larky D, Chinipardaz R, Eskandary N, Mehavaran M. Inflammatory Biomarkers' Response to Two Different Intensities of a Single Bout Exercise Among Soccer Players. Iran Red Crescent Med J 2016; 18: e21498. http://dx.doi.org/ 10.5812/ircmj.21498.

11. Malm C, Nyberg P, Engstrom M, Sjodin B, Lenkei R, Ekblom B, Lundberg I. Immunological changes in human skeletal muscle and blood after eccentric exercise and multiple biopsies. J Physiol 2000; 529: 243-62.

12. Ziemann E, Zembron-Lacny A, Kasperska A, Antosiewicz J, Grzywacz T, Garsztka T, Laskowski R. Exercise training-induced changes in inflammatory mediators and heat shock proteins in young tennis players. J Sports Sci Med 2013; 12: 282-9.

13. Awasthi A, Murugaiyan G, Kuchroo VK. Interplay between effector Th17 and regulatory T cells. J Clin Immunol 2008; 28: 660-70.

14. Laurent X, Renault N, Farce A, Chavatte P, Hénon E. Relationships between Th1 or Th2 iNKT cell activity and structures of CD1d-antigen complexes: meta-analysis of CD1d-glycolipids dynamics simulations. PLoS Comput Biol 2014; 10: e1003902. http://dx.doi.org/ 10.1371/journal.pcbi.1003902.
15. Slobodin G, Rimar D. Regulatory T cells in systemic sclerosis: a comprehensive review. Clin. Rev Allergy Immunol 2017; 52: 194-201.

16. Wasinski F, Gregnani MF, Ornellas FH, Bacurau AV, Câmara NO, Araujo RC, Bacurau RF. Lymphocyte glucose and glutamine metabolism as targets of the anti-inflammatory and immunomodulatory effects of exercise. Mediators Inflamm 2014: 326803. http://dx.doi.org/10.1155/2014/326803.

17. Peake J, Nosaka K, Suzuki K. Characterization of inflammatory responses to eccentric exercise in humans. Exerc Immunol Rev 2005; 11: 64-85.

18. Carbo A, Hontecillas R, Kronsteiner B, Viladomiu $M$, Pedragosa M, Lu P, Philipson CW, Hoops S, Marathe M, Eubank S, Bisset K, Wendelsdorf K, Jarrah A, Mei Y, Bassaganya-Riera J. Systems modeling of molecular mechanisms controlling cytokine-driven CD4 $+\mathrm{T}$ cell differentiation and phenotype plasticity. PLoS Comput Biol 2013; 9: e1003027. http://dx.doi.org/10.1371/ journal.pcbi.1003027.

19. Peters A, Yosef N. Understanding Th17 cells through systematic genomic analyses. Curr Opin Immunol 2014; 28: 42-8.

20. Stumhofer JS, Silver J, Hunter CA. Negative regulation of Th17 responses. Semin. Immunol 2007; 19: 394-9.

21. Korn T, Oukka M, Kuchroo V, Bettelli E. Th17 cells: effector $\mathrm{T}$ cells with inflammatory properties. Semin Immunol 2007; 19: 362-71.

22. McGeachy MJ, Cua DJ. The link between IL-23 and Th17 cell-mediated immune pathologies. Semin Immunol 2007; 19: 372-6.

23. Nieman DC. Exercise immunology: practical applications. Int J Sports Med 1997;18 Suppl 1: S91-S100.

24. Beaver WL, Wassermann K, Whipp BJ. A new method for detecting anaerobic threshold by gas exchange. J Appl Physiol (1985) 1986; 60: 2020-7.

25. Smidowicz A, Regula J. Effect of nutritional status and dietary patterns on human serum $C$-reactive protein and interleukin-6 concentrations. Adv Nutr 2015; 6: 738-47.

26. Brown FF, Bigley AB, Sherry C, Neal CM, Witard OC, Simpson RJ, Galloway SD. Training status and sex influence on senescent T-lymphocyte redistribution in response to acute maximal exercise. Brain Behav Immun 2014; 39: 152-9.

27. Spielmann G, McFarlin BK, O'Connor DP, Smith PJ, Pircher $\mathrm{H}$, Simpson RJ. Aerobic fitness is associated with lower proportions of senescent blood T-cells in man. Brain Behav Immun 2011; 25: 1521-9.

28. Broz P, Rajdl D, Novak J, Hromadka M, Racek J, Trefil $\mathrm{L}$, Zeman V. High-sensitivity troponins after a standardized 2-hour treadmill run. J Med Biochem 2018; 37: 364-72.

29. Nieman DC. Current perspective on exercise immunology. Curr Sports Med Rep 2003; 2: 239-42.

30. Chen CY, Liao YH, Chou CC, Sung YC, Tsai SC. Initial systemic inflammatory state perturbs exercise training 
adaptations in elite Taekwondo athletes. PLoS One 2017; 12: e0176140. http://dx.doi.org/10.1371/ journal.pone.0176140.

31. Silveira Coswig V, Hideyoshi Fukuda D, de Paula Ramos $\mathrm{S}$, Boscolo Del Vecchio F. Biochemical Differences Between Official and Simulated Mixed Martial Arts (MMA) Matches. Asian J Sports Med 2016; 7: e30950. http://dx.doi.org/10.5812/asjsm.30950.
32. Yeh SH, Chuang H, Lin LW, Hsiao CY, Eng HL. Regular tai chi chuan exercise enhances functional mobility and CD4CD25 regulatory T cells. Br J Sports Med 2006; 40: 239-43.

33. Malm C. Exercise immunology: a skeletal muscle perspective. Exerc Immunol Rev 2002; 8: 116-67.

34. Suzuki K, Nakaji S, Yamada M, Liu Q, Kurakake S, Okamura N, Kumae T, Umeda T, Sugawara K. Impact of a competitive marathon race on systemic cytokine and neutrophil responses. Med Sci Sports Exerc 2003; 35: 348-55.

Received: August 5, 2018

Accepted: September 6, 2018 